\title{
The Impact of The Pandemic on The Economy of The Republic of Uzbekistan
}

\author{
Baykhonov Bahodirjon Tursunbaevich \\ Institute of Forecasting and Macroeconomic Research, group leader Doctor of \\ Economics \\ Mullabayev Baxtiyarjon Bulturbayevich \\ Namangan Engineering Construction Institute \\ Associate Professor of Management, Doctor of Philosophy in Economics (Phd) \\ mullaboev_b@mail.ru tell: +998939486868
}

\author{
Abdul Rahmat \\ Gorontalo State University Indonesia \\ abdulrahmat@ung.ac.id
}

Received: 02 Oktober 2020; Revised: 21 November 2020; Accepted: 28 Desember 2020 DOI: http://dx.doi.org/10.37905/aksara.7.1.137-146.2021

\begin{abstract}
In recent years, a number of radical reforms aimed at liberalizing the socioeconomic spheres of the country have been consistently carried out. In particular, a number of reforms aimed at liberalizing the foreign exchange market, tax reform aimed at increasing incomes and stimulating production, the gradual transition to medium-term budget planning, reducing the role of inflation targeting in the economy, gradual privatization of state enterprises and the introduction of market mechanisms. continues.
\end{abstract}

Keywords: economic growth, pandemic, aggregate demand, aggregate supply, macroeconomic stability, gross domestic product, foreign economic relations, forecast.

\section{Introduction}

The global spread of the coronavirus pandemic, which occurred in Wuhan, People's Republic of China, in November-December 2019, has created a global crisis. This is different from the global crises in many ways, showing that the negative impact on the economy is very strong. In economic terms, this pandemic is an external "blow" to aggregate demand and aggregate supply, macroeconomic stability, and differs greatly from previous economic crises in terms of scale and damage. In a short period of time, the global spread of the disease is having a negative impact on the economic and social situation in almost all countries. Also, the scope of the virus continues to expand. This, in turn, requires the development of measures to reduce the impact of the pandemic in the country and the development of the country's economy, as well as the adoption of science-based decisions. 
The degree to which the problem has been studied Economic growth has emerged as the latest phenomenon in human civilization, and much scientific research is being done on this subject. In particular, the American economist E. While studying the history of economic growth from 500 AD, Maddison identified a clear link between the growth of adequate output per capita and population growth over the last 1,500 years into four periods [1]. S. Kuznets argues that "the rate of economic growth in countries such as the United Kingdom, Germany, and the United States is related to the industrial revolution and the period when capitalism became the leading economic system."

According to Weber, while Eastern religion served as a barrier to industrial growth in countries such as China and India, it became a serious factor in Western economic growth and modern Western civilization [3]. "Effective organization of the economy," says American economist D. Nore, "is the key to economic growth." Its emergence in Western Europe may have been conditioned by the rise of the West.

Consumption of food and agricultural goods is limited, which means that the share of expenditures on food in the structure of consumer demand decreases with the growth of per capita income. Such a conclusion was given by the German statistician E. Engel in the last century, and E. Engel named it the first law. (E. Engel's second law applies to industrial consumer goods and valuables. As the per capita income increases, so does the share of household expenditures on this commodity group.) [5]

The British economist K. Clark confirmed Engel's conclusions on the basis of new empirical data and stated that "the decrease in the share of the agricultural sector is first considered an increase in the share of industry, and then the growth of the service sector" [6].

Evsey Domar, an American economist and neo-Keynesian, also proposed a slightly different model of proportional economic growth, unaware of R. Harrod's research. He adds that J.M. Keynes argues that investment increases demand through the formation of income, and that investment also leads to an increase in the supply of goods. In the E. Domar and R. Harrod models, investments are cited as a stimulus for economic growth because they have a multiplier effect and therefore ensure sustainable growth.

In his model, Robert Solow, a representative of neoclassical theory, identified the mechanism by which savings, labor force growth, and scientific and technological progress affect the living standards of the population and its dynamics [8]. R. Solow's main conclusion is that in the long run, economic growth rates will depend not on the growth of capital investment, but on the factor of technological development.

Research method. In the study, the views of international scholars on economic growth were widely observed, the factors related to economic growth were selected and their correlation was determined using correlation analysis. Economic and statistical analyzes were conducted, and forecasting methods of socio-economic development of the Republic of Uzbekistan under the influence of the pandemic on the basis of econometric models were used. identified, a comparative analysis of the results of the initial, targeted forecast until 2030 was carried out, and proposals and recommendations for the future to achieve it were developed.

The results of the analysis

At present, a number of radical reforms aimed at liberalizing the socioeconomic spheres of the country are being carried out. In particular, a number of 
reforms aimed at liberalizing the foreign exchange market, tax reform aimed at increasing incomes and stimulating production, the gradual transition to mediumterm budget planning, reducing the role of inflation targeting in the economy, gradual privatization of state enterprises and the introduction of market mechanisms. continues.

The global spread of the coronavirus pandemic, which occurred in Wuhan, People's Republic of China, in November-December 2019, has created a global crisis. This is different from the global crises in many ways, showing that the negative impact on the economy is very strong. In economic terms, this pandemic is an external "blow" to aggregate demand and aggregate supply, macroeconomic stability, and differs greatly from previous economic crises in terms of scale and damage. In a short period of time, the global spread of the disease is having a negative impact on the economic and social situation in almost all countries. Also, the scope of the virus continues to expand.

In this regard, the coronavirus pandemic also has a negative impact on the targets of the Republic of Uzbekistan for the next 10 years, and in this regard it is necessary to revise the changes in the economy and the target forecast to determine in a timely manner what measures to reduce its impact.

In particular, the GDP in 2020 is projected to be 580924.6 billion soums, which is $72,621.4$ billion soums less than the forecast of $2020(653,546$ billion soums) in the pre-pandemic period. The main reasons for this are strict quarantine measures lasting almost 4 months, as well as the negative impact of global economic growth, declining international trade in goods and services, declining tax revenues, and more. It should also be noted that the forecast of $4.3 \%$ of economic growth rates until 2030 may reflect the negative impact of the coronavirus pandemic over the next 10 years (the average forecast of economic growth until 2030 was $6.4 \%$ ). In addition, the decline in the average economic growth rate to almost $2.1 \%$ in the period up to 2030 is due to the $1 \%$ economic growth rate in 2020 and the downward trend in economic growth from 2022 onwards.

Based on the above, it is important to divide 2020-2030 into 2 parts. That is, these periods are short-term and long-term (the last 10 years are " $2+8 ")$. In the first period, ie in 2020-2021, as a result of the implementation of decisions and decrees of the Government to mitigate the negative impact of the crisis on sectors of the economy, support sectors of the economy and businesses, the country's GDP growth rate is expected to reach $101 \%$ in 2020. while in 2021 it will be $105.8 \%$. 
Table 1

Forecast of socio-economic development of the Republic of Uzbekistan until 2025 after the Coronavirus pandemic

\begin{tabular}{|c|c|c|c|c|c|c|c|}
\hline Indicators & $\mathbf{2 0 1 9}$ & $\mathbf{2 0 2 0}$ & $\mathbf{2 0 2 1}$ & $\mathbf{2 0 2 2}$ & $\mathbf{2 0 2 3}$ & $\mathbf{2 0 2 4}$ & $\mathbf{2 0 2 5}$ \\
\hline $\begin{array}{c}\text { GDP, billion, } \\
\text { soums }\end{array}$ & 511838,1 & $580924,6687715,7$ & $807673,9941588,8$ & 1090249,8 & 1254446,4 \\
\hline $\begin{array}{c}\text { Growth rate, in } \\
\text { percent }\end{array}$ & 105,6 & 101,0 & 105,8 & 105,4 & 105,1 & 104,8 & 104,6 \\
\hline $\begin{array}{c}\text { Real GDP, billion } \\
\text { soums }\end{array}$ & 429394,4 & $516721,4614593,9$ & 725063,8 & 848959,9 & 987116,3 & 1140372,8 \\
\hline $\begin{array}{c}\text { GDP per capita, } \\
\text { billion soums }\end{array}$ & 15391.1 & 17133.8 & 19944.4 & 23031.8 & 26401.7 & 30059.1 & 34008.0 \\
\hline $\begin{array}{c}\text { Real GDP per } \\
\text { capita, billion } \\
\text { soums }\end{array}$ & 12911,9 & 15240.2 & 17823.8 & 20676.0 & 23804.4 & 27215.6 & 30915.4 \\
\hline Deflator & 19,2 & 12,4 & 11,9 & 11,4 & 10,9 & 10,4 & 10,0 \\
\hline
\end{tabular}

The table shows that economic growth is projected to reach $101.8 \%$ in 2020 and $101.8 \%$ in 2021 as a result of the negative impact of the coronavirus pandemic. It is also projected that the GDP rate will not fall below 5\% on average over the last 4 years.

In 2022, the GDP growth rate will be $105.4 \%$, in $2025-104.6 \%$, ie the GDP growth rate is expected to decrease, and it is expected to increase 1.6 times from 2020 to 2030 (the previous target was 2 times by 2030). According to the preliminary forecast parameters, the Decree of the Central Bank of the Republic of Uzbekistan "On improving monetary policy through the gradual transition to inflation targeting" [9] will reduce inflation to $10 \%$ in 2021 and set a fixed inflation target of 5\% in 2023. It was stipulated that from January 1, 2020, the monetary policy mechanisms should be gradually transferred to the inflation targeting regime. However, the increase in the exchange rate as a result of the global economic crisis and the increase in aggregate demand as a result of stimulating aggregate supply are expected to increase inflation expectations to fall to the target level of inflation (9.6\%) by 2026 and $8 \%$ in 2030.

The reason for such a sharp increase in economic growth was the work done during the coronavirus pandemic to support the economy, mainly to support the population, taxpayers and all sectors of the economy, including entrepreneurship. In particular, "On priority measures to mitigate the negative impact of the coronavirus pandemic and the global crisis on sectors of the economy" [10] and "On additional measures to support the population, industries and businesses during the coronavirus pandemic" [11]. ] gi can be mentioned in connection with the granting of a number of privileges in accordance with the decrees.

\section{Discussion of results}

- To forecast the socio-economic development of the country in the long run, the following tasks should be performed (in 2030):

- Ensuring macroeconomic stability, implementation of fiscal rules and criteria for cost-effectiveness, transition to a policy of targeting strict inflation, 
gradual introduction of international requirements for financial stability indicators of the country, rapid development of capital and securities markets;

- Development of the processing industry, increasing the efficiency of resource use, the transition to an active export-oriented policy, encouraging the use of non-conventional resources and energy sources in production, focusing on the use of resource-saving and green economy in production;

- Development of science-based economy, widespread introduction of public-private partnership in the system, increasing the level of sports, increasing the coverage of compulsory health insurance to $90 \%$, applying international standards to the system of qualification assessment of health workers, raising living standards to advanced countries ;

\section{Conclusion}

In short, by 2030 it is necessary to form a socially oriented market economy through the development of a real sector based on high human capital, innovation and resultoriented investment policy, to ensure the country's inclusion in the group of middleincome countries according to the World Bank.

Ensuring macroeconomic stability, which is the basis for long-term socio-economic development of the country, clearly defining the growth points of the real sector, implementing effective ways of human capital development, creating an innovative model of economic development, effective use of natural and economic factors, economic growth and structural change priorities for the implementation of results-oriented investment policy should be identified.

\section{References}

Мэдисон Э. Контуры мировой экономики в 1-2030 гг.: очерки по макроэкономической истории: пер. с англ. - М.: Ин-т Гайдара, 2015. - 582 c.

Kuznets S. Driving Forces of Economic Growth: What Can We Learn from History? // Weltwirschaftliches Archiv, 1981, v.116, p.409-431 (reprinted in: H.Giersch (ed.). Towards an Explanation of Economic Growth. Tubingen, 1981).

Вебер, Ал. Германия и кризис европейской культуры / Ал. Вебер ; пер. Т.Е. Егорова. - Москва : Директ-Медиа, 2007. - 84 с. - Режим доступа: по подписке. - URL: http://biblioclub.ru/index.php?page=book\&id=36072. ISBN 978-5-94865-984-8.

Douglass C. North. Institutions and Economic Growth: An Historical Introduction // World Development, 1989, vol.17, no.9, p.1319-1332. (C) Pergamon Press, 1989.

Zimmerman, C. 1932. "Ernst Engel's law of expenditures for food". The Quarterly Journal of Economics. Vol. 47, No. 1 (Nov.), pp 78-101.

Большой экономический словарь / под ред. А.Н. Азаряна. - 7-е изд. -М.: Институт новой экономики, 2008. - С. 597-601.

Harrod-Domar Model. Anim Publishing, 2011. P. 21.

Solow, Robert M. A Contribution to the Theory of Economic Growth. // Quarterly Journal of Economics 70 (February), 1956. P. 65-94. 
Ўзбекистон Республикаси Президентининг “Инфляцион таргетлаш режимига босқичма-босқич ўтиш орқали пул-кредит сиёсатини такомиллаштириш тўғрисида"ги 2019 йил 18 ноябрдаги ПФ-5877 сонли Фармони. Lex. uz

Ўзбекистон Республикаси Президентининг 2020 йил 19 мартдаги «Коронавирус пандемияси ва глобал инқироз холатларининг иқтисодиёт тармоқларига салбий таъсирини юмшатиш бўйича биринчи навбатдаги чора-тадбирлар тўғрисида»ги ПФ-5969-сонли фармони. Lex. Uz.

2020 йил 3 апрелдаги "Коронавирус пандемияси даврида ахоли, иқтисодиёт тармоқлари ва тадбиркорлик субъектларини кўллаб-қувватлашга доир кўшимча чора-тадбирлар тўғрисида"ги ПФ-5978-сонли фармони. Lex. Uz

Ismoilov Ravshanjon Bakhriddinovich, Mullabayev Baxtiyarjon Bulturbayevich, Mahmudova Nilufar Gulomjanovna, Usmonov Rustamjon Karimjanovich, and Bakhriddinov Jahongir Ravshanjon ogli, "USE OF MODERN MARKETING RESEARCH IN THE CONTEXT OF MARKET DEVELOPMENT”, IEJRD - International Multidisciplinary Journal, vol. 5, no. Special Issue, p. 8, Oct. 2020.

Bulturbayevich, M. B., Saodat, S., \& Shakhnoza, N. (2020). INNOVATIVE ACTIVITY OF SMALL BUSINESSES IS AN IMPORTANT TOOL FOR CREATING PRODUCTIVE JOBS. International Engineering Journal For Research \& Development, 5(6), 9-9.

Bulturbayevich, M. B., \& Jurayevich, M. B. (2020). THE IMPACT OF THE DIGITAL ECONOMY ON ECONOMIC GROWTH. International Journal of Business, Law, and Education, 1(1), 4-7. Bulturbayevich, M. B., \& Jurayevich, M. B. (2020). THE IMPACT OF THE DIGITAL ECONOMY ON ECONOMIC GROWTH. International Journal of Business, Law, and Education, 1(1), 4-7.

Jurayevich, M. B., \& Bulturbayevich, M. B. (2020). ATTRACTING FOREIGN INVESTMENT IN THE AGRICULTURAL ECONOMY. International Journal of Business, Law, and Education, 1(1), 1-3. Jurayevich, M. B., \& Bulturbayevich, M. B. (2020). ATTRACTING FOREIGN INVESTMENT IN THE AGRICULTURAL ECONOMY. International Journal of Business, Law, and Education, 1(1), 1-3.

Mamadaliyevich, S. A., Bulturbayevich, M. B., \& Shokirjonovich, A. M. (2020). WAYS TO INCREASE THE COMPETITIVENESS OF NATIONAL GOODS IN DOMESTIC AND FOREIGN MARKETS. International Engineering Journal For Research \& Development, 5(6), 6-6.

Madrahimovich, R. N., \& Bulturbayevich, M. B. (2019). Advantages of vertical integrated enterprises (under light industry enterprises). Test Engineering and Management, 81(11-12), 1596-1606.

Bulturbayevich, M. B., \& Sharipdjanovna, S. G. (2020). Improving the efficiency of management of vertical integrated industrial enterprises. Test Engineering and Management, 83, 5429-5440.

Mullabayev Baxtiyarjon Bulturbayevich, Mirzabdullayeva Gulnora, Inamova Guligavkhar. (2020). Analysis of Macroeconomic Indicators and Forecast of Scenarios of the Republic of Uzbekistan. International Journal of Advanced Science and Technology, 29(11s), 04 - 12. Retrieved from http://sersc.org/journals/index.php/IJAST/article/view/19921 
Mullabayev Baxtiyarjon Bulturbayevich, Inamova Guligavkhar, Umarova Gulchekhra. (2020). Issues Of Development Of Light Industry Enterprises Through Modern Management Mechanisms And Forecasting Of Corporate Structures On The Basis Of Vertical Integration Processes. International Journal of Advanced Science and Technology, 29(11s), 1975 1986. Retrieved from http://sersc.org/journals/index.php/IJAST/article/view/21866

Mullabayev Baxtiyarjon Bulturbayevich, Saydullaeva Saodat, Juraeva Umida, Nurullaeva Shakhnoza, \& Shamsieva Feruza. (2020). MECHANISMS OF STATE INCENTIVES FOR LOGISTICS CENTERS TO ENSURE THE COMPETITIVENESS OF THE ECONOMY. International Engineering Journal For Research \& Development, 5(5), 7. Retrieved from http://iejrd.com/index.php//article/view/1117

Ismoilov R. B., Mullabayev B. B., Abdulxakimov Z. T. Prospects For The Development Of A Tourist Route" Safed Broth Or Horn Jarir" //The American Journal of Interdisciplinary Innovations and Research. - 2020. - T. 2. - №. 08. - C. 3844.

Ismoilov, R. B., Mullabayev, B. B., Abdulxakimov, Z. T., \& Bakhriddino, J. R. O. (2020). The Essence Of Small Business And Private Entrepreneurship And The Theoretical Basis Of Its Development. The American Journal of Applied sciences, 2(08), 45-50.

Косимова, Д. (2020). Improvement of the strategy of vertical integration in industrial enterprises. Архив научных исследований.

Bulturbayevich, M. B., Sharipdjanovna, S. G., Ibragimovich, A. S., \& Gulnora, M. (2020). MODERN FEATURES OF FINANCIAL MANAGEMENT IN SMALL BUSINESSES. International Engineering Journal For Research \& Development, 5(4), 5-5.

Jurayevich, M. B., \& Bulturbayevich, M. B. (2020). ATTRACTING FOREIGN INVESTMENT IN THE AGRICULTURAL ECONOMY. International Engineering Journal For Research \& Development, 5(2), 3-3.

Sobirovna, Q. D., Abdugafarovich, S. A., \& Bulturbayevich, M. B. (2019). Improvement of the strategy of vertical integration in industrial enterprises. American Journal of Economics and Business Management, 2(3), 63-68.

Mullabaev, B. B., Vohidov, E., \& Karimov, D. (2019). ROLE OF VERTICALLY INTEGRATED ENTERPRISES IN THE ECONOMY. Theoretical \& Applied Science,(1), 85-90.

Sholdarov, D., \& Mullaboev, B. (2019). Problems of supporting financial stability of the pension supply system in Uzbekistan. Theoretical \& Applied Science, (2), 344349.

Mullabaev, B. B. (2018). ECONOMETRIC ANALYSIS OF VERTICAL INTEGRATION OF THE LIGHT INDUSTRY ENTERPRISES OF THE NAMANGAN REGION (ON THE EXAMPLE OF THE REPUBLIC OF UZBEKISTAN). Scientific Review: Theory and Practice,(8), 22, 36.

Зайнутдинов, Ш., \& Муллабаев, Б. (2018). Ўзбекистонда иқтисодий интеграцияни ривожлантириш ва унинг самарадорлигини ошириш омиллари. Бизнесэксперт журнали, 30. 
Mullabayev, B. B. (2018). Economic analysis of vertical integration integration of the Namangan region (on the prerogative of the Republic of Uzbekistan). Science of theory: theory and practice"-8.

Zaynutdinov, S. N., \& Mullabayev, B. B. (2018). REGIONAL EFFECTIVENESS OF THE REGIONS. Economics and Innovative Technologies, 2018(1), 9.

Mullabaev, B. (2017). DEVELOPMENT OF LIGHT INDUSTRY BRANCHES IN UZBEKISTAN BASED ON VERTICAL INTEGRATION. Бюллетень науки и практики, (10), 178-184.

Bachtijarzhan, M. (2017). DEVELOPMENT OF LIGHT INDUSTRY BRANCHES IN UZBEKISTAN BASED ON VERTICAL INTEGRATION. Бюллетень науки и практики, (10 (23)).

Dadaboyev, T. Y., Qoraboyev, S. A., \& Mullabaev, B. B. (2017). CORPORATE MANAGEMENT AS THE FACTOR OF INVESTMENT ATTRACTION. Научное знание современности, (5), 77-80.

Муллабоев, Б. Б. (2015). Корпоративное управление как способ привлечения инвестиции. Молодой ученый, (10), 749-751.

Mullaboev, B. B. (2015). Corporate governance as a way to attract investment. Young scientist, (10), 749-751. 